Chapter 37 in Xu Wen and John R. Taylor (Eds.) (2021) The Routledge Handbook of Cognitive Linguistics, pp. 387-407. Downloadable from https://psyarxiv.com/prm7u/Preprint DOI 10.31234/osf.io/prm7u

\title{
Culture in language and cognition
}

\author{
Chris Sinha
}

\section{Abstract}

This Handbook chapter provides an overview of the interdisciplinary field of language, cognition and culture. The chapter explores the historical background of research from anthropological, psychological and linguistic perspectives. The key concepts of linguistic relativity, semiotic mediation and extended embodiment are explored and the field of cultural linguistics is outlined. Research methods are critically described. The state of the art in the key research topics of colour, space and time, and self and identities is outlined.

\section{Introduction}

\section{Independence versus interdependence of language, mind and culture}

Cognitive Linguistics (CL) was forged in the matrix of cognitive sciences as a distinctive and highly interdisciplinary approach in linguistics. Foundational texts such as Lakoff (1987), Langacker (1987) and Talmy (2000) drew upon long but often neglected traditions in cognitive psychology, especially Gestalt psychology (Sinha 2007). A fundamental tenet of $C L$ is that the cognitive capacities and processes that speakers and hearers employ in using language are domain-general: they underpin not only language, but also other areas of cognition and perception. This is in contrast with Generative (or Formal) Linguistics, to which $\mathrm{CL}$ historically was a critical reaction, which takes a modular view of both the human language faculty and of its subsystems. For Generative Linguists, not only is the subsystem of syntax autonomous from semantics and phonology, but language as a system is autonomous both from other cognitive processes, and from any influence by the culture and social organization of the language community. There is one significant exception to this, which is that all linguists will agree that the lexicon of a language is affected by culture (including both names for natural kinds and names for artefacts and institutions). However, Generative Linguists maintain that the grammatical features of languages are entirely independent of cultural patterns. In cognitive and construction grammars, the distinction between lexicon and grammar is less categorical than in formal linguistics (Langacker 1987; Kay and Fillmore 1999). If language affords a window into the mind, and if there are differences in individual minds as a result of differences in the cultures that form these minds, then language (at all levels of analysis) will also provide a window into culturally specific cognition. This is the promise of a cultural 
Chapter 37 in Xu Wen and John R. Taylor (Eds.) (2021) The Routledge Handbook of Cognitive Linguistics, pp. 387-407. Downloadable from https://psyarxiv.com/prm7u/ Preprint DOI 10.31234/osf.io/prm7u

linguistics based upon CL. Furthermore, since Cognitive Linguists believe that all the linguistic facts of a language, including grammatical facts, are motivated by meaning, and culture is fundamentally about meaning and variations between human groups in their organization of meaning (Sinha 2017a), then a cultural linguistics will be based on the assumption that language, culture and mind are mutually interdependent, rather than independent (Sinha 2017b).

\section{What is culture?}

What the word 'culture' means has been the subject of much debate and disagreement. A much-cited early definition is that of the $19^{\text {th }}$ century British anthropologist E.B. Tylor: "that complex whole which includes knowledge, belief, art, morals, law, custom, and any other capabilities and habits acquired by man as a member of society." ${ }^{1}$ This definition has frequently been criticized, however, as being both too vague, and neglectful of the importance of the fact that cultures are different from one another. By the mid-twentieth century anthropologists Kroeber and Kluckhohn (1952) were able to cite no less than 164 definitions of culture, settling themselves on the following: "Culture consists of patterns, explicit and implicit, of and for behaviour acquired and transmitted by symbols, constituting the distinctive achievements of human groups, including their embodiments in artefacts ... culture systems may, on the one hand, be considered as products of action, and on the other as conditioning elements of further action." This definition stresses the importance of symbols, artefacts and action, but (in keeping with the behaviourist tenor of the time when it was written) neglects the importance of the cognitive foundations that support these.

Sinha (2017b: 9) places meaning at the centre of the definition of culture, proposing that any human culture should be thought of as "a pattern or patterns of meaning ... a normative order, realized and reproduced in semiotic systems or vehicles including language, and in enduring artefacts and institutions; and enacted and renewed in social and communicative practices." Sinha (op cit.) also emphasizes that culture can be conceptualized from three equally valid perspectives: Ways of doing things (practices); Ways of thinking and feeling (mental models, schemas, worldviews, ideologies, structures of feeling); and Ways of talking (discourses). All of these perspectives have been influential in the history of thought about language and culture in different disciplines. 
Chapter 37 in Xu Wen and John R. Taylor (Eds.) (2021) The Routledge Handbook of Cognitive Linguistics, pp. 387-407. Downloadable from https://psyarxiv.com/prm7u/ Preprint DOI 10.31234/osf.io/prm7u

\section{Historical Perspectives}

\section{Anthropological Perspectives}

The discipline that is historically, and to this day remains, most centrally concerned with culture is anthropology. In a way, the history of the discipline of anthropology is the history of its changing conceptualizations of culture. Throughout the $19^{\text {th }}$ century, the predominant perspective was a culturalevolutionary one, in which different human groups were thought of as existing on a universal scale of complexity and sophistication. In the influential theory of Lewis Henry Morgan (1877), society and culture progress from savagery through barbarism to civilization. This evolutionism underpinned a Eurocentric, implicitly (and in its Social Darwinist variants, explicitly) racist phylocultural complex (Sinha 1988), which included the assumption that "primitive languages" lacked the complexity and clarity of the languages of "civilized" peoples.

This prejudiced and scientifically ill-informed view was challenged and overthrown by the American anthropologist Franz Boas, one of the founding fathers-along with Bronislaw Malinowski, who coined the term "ethnolinguistics" (Senft 2007) - of linguistic anthropology, and the principal forerunner of contemporary cultural linguistics. ${ }^{2}$ Anthropology's serious engagement with the relationship between cultures and languages began with Boas's field studies of Native American languages, culminating in the publication in 1911 of the Handbook of American Indian Languages. ${ }^{3}$ In the Introduction to this epochal work Boas explicitly acknowledged the mutual inter-relationships between language, mind and culture. "The purely linguistic inquiry", he wrote, "is part and parcel of a thorough investigation of the psychology of the peoples of the world" (Boas, 1911: 63). Boas believed in the 'psychic unity of mankind' (Köpping, 1983), that is, that all human beings possess the same fundamental psychological capacities and that there exist "uniform laws governing the human mind" (Boas 1896: 901). He also held that "the occurrence of the most fundamental grammatical concepts in all languages must be considered as proof of the unity of fundamental psychological processes." (Boas 1911: 71).

Boas recognized that cultures transmit learned and distinctive ways of thinking, and that this transmission occurs via language, while arguing against the idea that either language or culture sets a limit on the potential for either individuals or societies to acquire new modes of thought. For example, he noted (correctly) that "many languages exist in which the numerals do not exceed two or three", a fact that he attributed to the social practices of the group: "counting does not become necessary until objects are considered in such generalized form that their individualities are entirely lost sight of." 
Chapter 37 in Xu Wen and John R. Taylor (Eds.) (2021) The Routledge Handbook of Cognitive Linguistics, pp. 387-407. Downloadable from https://psyarxiv.com/prm7u/ Preprint DOI 10.31234/osf.io/prm7u

However, "there is no proof that the lack of the use of numerals is in any way connected with the inability to form the concepts of higher numbers" (Boas 1911: 66). The general position arrived at by Boas was that "the form of the language will be moulded by the state of culture, but not in so far as a certain state of culture is conditioned by morphological traits of the language" (Ibid. p. 67).

Boas (1896) was the first anthropologist to advocate (against the evolutionism of Tylor and Morgan) the theoretical and methodological stance that would later be called cultural relativism: the proposition that the ideas, values and practices of each culture should be understood in terms of the complex whole of the culture, rather than in terms of some presumed universal evolutionary scale. ${ }^{4}$ This relativistic stance informs the methodological distinction, common to ethnographic approaches in both linguistics (Pike 1975) and psychology (Berry 1969) as well as anthropology, between emic (study of cultural and linguistic forms in an internalist framework) and etic (study of cultural and linguistic forms from an external, comparativist perspective) approaches. Because of Boas's passionate determination to record and document the endangered, often dying, languages of Native North American cultures, his and his students' work also anticipated and laid the ground for contemporary approaches to the documentation of endangered languages. It is important to note that for Boas the description and analysis of endangered languages was not a sub-discipline of linguistics. Language description was intrinsically inseparable from ethnographic studies. Indeed, Boas was the originator of the "four field approach", still key to anthropology in the United States, according to which the discipline consists of the sub-fields of archaeology, linguistics, physical anthropology and cultural anthropology. Several scholars have recently criticized mainstream approaches in present-day documentary linguistics as having neglected (in their pursuit of methodological rigour and uniformity) this all-important interdisciplinary and social scientific matrix (Austin 2016; Grinevald and Sinha 2016).

Because of an increasing gulf between linguistic and anthropological theories, the Boasian tradition came to be associated in the second part of the $20^{\text {th }}$ century with a predominantly grammatically oriented descriptive linguistics. Anthropological linguistics no longer shared theoretical foundations with the newly emerging currents in the microsociology of communication (Goffman 1967), conversation analysis (Sacks et al. 1974) and symbolic and critical anthropology (Geertz 1973; Clifford and Marcus 1986). A new approach to anthropology of language, ethnography of communication (Gumperz and Hymes 1972), gained ground, whose practitioners "[broke] with the Boasian tradition of conceiving culture as a mental phenomenon, tending to neglect issues of 'knowledge' in favor of 'performance'"' 
Chapter 37 in Xu Wen and John R. Taylor (Eds.) (2021) The Routledge Handbook of Cognitive Linguistics, pp. 387-407. Downloadable from https://psyarxiv.com/prm7u/Preprint DOI 10.31234/osf.io/prm7u

(Duranti 2003: 328). It is this approach that, especially in United States, came to be identified with the term 'linguistic anthropology'. However, the resurgence of research in linguistic relativity (see below) in the late $20^{\text {th }}$ century has brought renewed interest amongst anthropologists in the Boasian tradition; as well as its reincarnation (amongst linguists) in the "new" field of cultural linguistics.

\section{Psychological Perspectives}

A cornerstone of the $19^{\text {th }}$ century phylocultural complex was the view that the non-European "savage mind" was less developed and more "child-like" than that of white Westerners. As Tylor (1865: 125) put it: "Between our clearness of separation of what is in the mind from what is out of it, and the mental confusion of the lowest savage of our own day, there is a vast interval". This notion of "mental confusion' was later transformed by anthropologist and sociologist Lévy-Bruhl (1910) into a theory of 'pre-logical primitive thought', a terminology he later rejected because of its overt Eurocentrism, and in light of his acceptance that "the fundamental structure of the human mind is the same everywhere" (Lévy-Bruhl 1949, cited by Pertierra 1983: 114). Lévy-Bruhl's fundamental proposition, in his later work, was that although individual mental capacities are universal (psychic unity), the mode of thinking of premodern societies is different from that of modern societies (relativity). In a way, Lévy-Bruhl's theory can thus be said to occupy a halfway house between the imperial and racial fantasies of the phylocultural complex, and $20^{\text {th }}$ century cultural and linguistic relativism.

The work of Lévy-Bruhl had a major impact on early $20^{\text {th }}$ century psychology, especially the two preeminent theorists of mind and language, Jean Piaget and Lev Vygotsky, both of whom drew parallels between the thought of children and the thought of non-Western cultures. As Peterman (2000: 405) puts it: "Lévy-Bruhl studied sociogenesis in the contrast between primitive and modern mentalities; Piaget studied psychogenesis in an analogous contrast between child and adult mentalities." In their later work, Piaget and Vygotsky both disavowed this parallelism, but they remained influenced by LévyBruhl's ideas, even while their theories of the relationship between cognitive development and child language development significantly diverged. ${ }^{5}$

Piaget accorded priority to the development of cognition through coordinations of action resulting in increasingly complex operational schemas, and he viewed language development as being governed by the development of nonlinguistic cognition. Vygotsky, in contrast, argued that language and other signs played a crucial role in the child's development to formal reasoning. Piaget was a universalist: he claimed that all children progressed through the same developmental stages, only the rate of 
Chapter 37 in Xu Wen and John R. Taylor (Eds.) (2021) The Routledge Handbook of Cognitive Linguistics, pp. 387-407. Downloadable from https://psyarxiv.com/prm7u/Preprint DOI 10.31234/osf.io/prm7u

development being influenced by social and cultural factors. For Vygotsky, by contrast, "higher psychological functions" (including memory and reasoning) are shaped by the cultural forms that they take in any given society, and are semiotically mediated - that is, it is the acquisition and use of linguistic and other signs that enables the development of the psychological function. As Vygotsky wrote: "The internalization of cultural forms of behavior involves the reconstruction of psychological activity on the basis of sign operations ... The internalization of socially rooted and historically developed activities is the distinguishing feature of human psychology" (Vygotsky 1978: 57-58).

Since he held that human cognition is embodied not only in the brain, but also in the products of material and symbolic culture (in tools, artefacts and signs, including the signs of language), Vygotsky and his colleagues sought to investigate cultural differences in both human development and in adult cognition. To this end, they conducted in the early 1930s a series of studies of changes in higher cognitive processes concomitant with the social transformations wrought by the collectivization of agriculture in Uzbekistan (Luria, 1976). This study was an early example of cross-cultural psychology, and set the scene for later research such as that of Michael Cole and colleagues (Cole, Gay, Glick, \& Sharp, 1971), employing a methodology that they dubbed 'experimental anthropology' to investigate the influence of schooling on modes of thought in Liberia.

Cole and his colleagues' research helped to change the terminology of the 'culture and thought' nexus. Moving beyond the idea of a uniform distinction between more and less 'advanced' societies, and between 'logical' and 'non-logical' thinking, they focused instead on the ways in which transcultural cognitive resources are brought to bear on different problem areas, in different contexts of reasoning and communication. Their "major conclusion" was that "cultural differences in cognition reside more in the situations to which particular cognitive processes are applied than in the existence of a process in one cultural group and its absence in another" (Cole et al. 1971: 233).

In the late $20^{\text {th }}$ century, studies of culture and mind underwent a further paradigm shift, from crosscultural psychology (which conceptualized its object as 'culture and psychology'), to an interdisciplinary cultural psychology, with a focus on "the systemic and dynamic nature of culture in psychology, and psychology in culture ... Culture is not an 'independent' variable, but a label that denotes the systemic organization of the semiotic and historical nature of human psychological processes" (Valsiner 1995: 7). (Valsiner, 1995) This Vygotskian-inspired theoretical approach includes cultural comparisons, and interfaces with ethnographic studies of socially and communicatively situated cognition and learning 
Chapter 37 in Xu Wen and John R. Taylor (Eds.) (2021) The Routledge Handbook of Cognitive Linguistics, pp. 387-407. Downloadable from https://psyarxiv.com/prm7u/ Preprint DOI 10.31234/osf.io/prm7u

(Lave and Wenger 1991), as well as with radical enactivist accounts of the 'cultural permeation' of mind (Hutto et al. 2020).

\section{Linguistic Relativity}

The theory of linguistic relativity has its roots in European philosophy and cultural theory, especially the foundational research of polymath and educator Wilhelm von Humboldt (1999 [1836]), who wrote that "the diversity of languages is not a diversity of signs and sounds but a diversity of worldviews" (cited in Trabant 2000: 25). The more recent (and most often misunderstood and misrepresented) version is often referred to after its originators, Edward Sapir and Benjamin Lee Whorf, and had its origins in Boasian anthropological linguistics (Darnell 2006). Sapir was a student of Boas, and Whorf was a student of Sapir. Although Sapir and Whorf borrowed both terminology and intellectual inspiration from Einstein's theory of relativity, the theory developed directly out of Boasian relativism, as expressed by Sapir (1949: 153-155) : "The outstanding fact about any language is its formal completeness"; that is, there are no "primitive languages" that are restricted in expressive power on some hypothetical evolutionary scale, any more than the cultures of the world can be ranked on their primitivism vs. civilization. Boas tended, as we have seen, to emphasize 'psychic unity', while recognizing that languages can be expressive of cultural patterns. Sapir and Whorf took the Boasian approach one step further, or perhaps better said, placed a greater emphasis on the interdependency of language, culture and thought, a notion that had remained implicit rather than explicit in Boas's work. In the Sapir-Whorf theory, language both expresses cultural patterns and world view, and influences habitual ways of thinking in individual members of the speech community: "We see and hear and otherwise experience very largely as we do because the language habits of our community predispose certain choices of interpretation" (Sapir 1949: 69). Such 'predisposition', it should be noted, does not (as Boas had already emphatically pointed out) imply a limitation of thought by language.

However, the notion of a dynamic, triadic relationship in which "language, thought, and culture are deeply interlocked" (Gumperz and Levinson 1996: 2) was subsequently reduced and simplified (largely by experimental researchers) to just such a dyadic and unidirectional "linguistic determinism" - the determination of individual thought by language (Jourdan and Tuite 2006; Leavitt 2010). As Sinha and Jensen de López (2000: 27) put it: "reference to culture in views ranging from Humboldt, through Boas, to Sapir and Whorf, which refer to language and 'world view', [was] downplayed in the narrowing of the problem-field to one of individual psycholinguistic functioning." This reduction not only distorted the 
Chapter 37 in Xu Wen and John R. Taylor (Eds.) (2021) The Routledge Handbook of Cognitive Linguistics, pp. 387-407. Downloadable from https://psyarxiv.com/prm7u/ Preprint DOI 10.31234/osf.io/prm7u

representation of linguistic relativity theory in scientific and popular discourses, it also exaggerated the distinction between Whorf's alleged linguistic determinism and Boas's acceptance of psychic unity (Lee, 1996). Linguistic determinism (and psychological relativism) is often attributed to Whorf on the basis of the following quotation (2012: 213-221): "We cut nature up, organize it into concepts, and ascribe significances as we do, largely because we are parties to an agreement to organize it in this way an agreement that holds throughout our speech community and is codified in the patterns of our language ... Users of markedly different grammars are pointed by their grammars toward different types of observations and hence different evaluations of externally similar acts of observation, and hence are not equivalent as observers but must arrive at somewhat different views of the world." In fact, however, Whorf was by no means an unconstrained relativist with respect to psychology, believing (in anticipation of $\mathrm{CL}$ theories) that "Gestalt psychology gives us a canon of reference for all observers, irrespective of their languages" (Whorf 2012: 163). During the 1950s, however, it was the linguistic determinist version of the "Whorf hypothesis", further simplified by the assumption that the hypothesis applied mainly or exclusively to the lexicon, that began to be tested by experimental psycholinguists in relation to the domain of colour (see below). This research was influential, in the wake of the 'first cognitive revolution', in leading to a consensus that Whorf was fundamentally wrong, a view that went largely unchallenged until the 1990 s.

A milestone in the re-evaluation of the theory of linguistic relativity was the publication of John Lucy's two volumes of historical-theoretical and empirical studies (Lucy 1992a,b) in which he argued (consistently with Whorf's own writings) for the primacy of grammatical over lexical linguistic diversity in the empirical investigation of the effects of linguistic categorization on non-linguistic cognition. Although Lucy acknowledged the situatedness of language (especially language use) in culture, he argued for a methodological dissociation between language and culture in field research: "a true 'linguistic' relativity, insofar as it is an autonomous force, must, by definition, operate somewhat independently of a more general cultural relativity" (Lucy 1992a: 269).

Lucy's theoretical reconstruction of linguistic relativity, and his field-based comparative experimental methodology (which bears many resemblances to Cole's 'experimental anthropology', see above) were influential in the large-scale cross-linguistic studies of spatial frames of reference (see below) in language and cognition carried out at the Max-Planck Institute for Psycholinguistics under the leadership of Stephen Levinson $(1996,2003)$. The general theory of method that inspired this work, and much 
Chapter 37 in Xu Wen and John R. Taylor (Eds.) (2021) The Routledge Handbook of Cognitive Linguistics, pp. 387-407. Downloadable from https://psyarxiv.com/prm7u/ Preprint DOI 10.31234/osf.io/prm7u

subsequent "neo-Whorfian" research, requires the identification of linguistic typological parameters in order to investigate their correlation with, and putative causation of, cross-linguistic cognitivebehavioral differences, independently of other dimensions of cultural variation. The treatment of language variation and cultural variation as "independent variables", and the methodological individualism inherent in behavioural experimentation, conflict with the methodological stance of $21^{\text {st }}$ century cultural psychology (see above), that attempts to explore "culture in mind and mind in culture". However, if neo-Whorfian research can be criticized for its over-emphasis on the relative autonomy of typological features of language from culture and social organization, cultural psychological research can also be criticized for paying insufficient attention to language-specific (including typological) aspects of the semiotic mediation of thought.

\section{Semiotic Mediation and Extended Embodiment}

Cognitive Linguistics takes as its starting point the idea that language affords us a window into the mind. Since language is based upon and exemplifies general properties and processes of human cognition, such as Figure-Ground organization, prototypicality in categorization and so on, the study of language is simultaneously the study of cognition: language is an expression of human cognitive processes, and cognition makes language possible. The notion of semiotic mediation rests upon a different intuition, which is that the "higher cognitive processes" (often held to be uniquely human) ${ }^{6}$ depend upon language and, more generally, upon the human use of signs (Mertz and Parmentier 1985). This idea, with roots in Leibniz's philosophy (Leavitt, 2010: 60, 73), had as its most celebrated early advocate the French Enlightenment philosopher Condillac, who wrote: "the mental operations of animals are limited to perception, consciousness, attention, reminiscence and imagination not under their control ... If contemplation consists in preserving perceptions, then before the use of institutional signs, it is merely outside our control ... as long as imagination and contemplation operate outside our control, we cannot direct our attention as we please ... But when someone begins attaching ideas to signs of his own choosing, we see his memory begin to form ... Later, he acquires much greater control over his imagination as he invents more signs, for he has many more ways of using it" (Condillac 1987 [1746]: 459). This was the seed of the concept of semiotic mediation conceived as a developmental process, which Vygotsky considered to be constitutive of uniquely human higher cognitive processes. From this perspective, language makes higher cognition possible. 
Chapter 37 in Xu Wen and John R. Taylor (Eds.) (2021) The Routledge Handbook of Cognitive Linguistics, pp. 387-407. Downloadable from https://psyarxiv.com/prm7u/ Preprint DOI 10.31234/osf.io/prm7u

Three important points need to be made here. First, the idea of language as a window into cognition and the idea of semiotic mediation, though apparently opposed, do not necessarily contradict each other: they can be viewed as complementary insights into the dynamic interdependency characterizing the language-thought relationship. Second, if cultures are viewed as "webs of significance" (Geertz 1973: 5), or meaning-bearing systems, then it is through semiotic mediation that culture permeates mind, as insisted by cultural psychology. Further, if these meaning-bearing systems (including language) vary between cultures, it is through semiotic mediation that cultural difference in minds is established and maintained. Third, semiotic mediation includes (but is not restricted to) the mediation of thought by language. It also includes mediation by other communicative signs such as gestures and icons, but also by material artefacts (Vygotsky used as an example the tying by a mother of a knot in her child's handkerchief to remind the child to give a message to the schoolteacher). Objects, therefore, also have meanings and can function as signs (Sinha 1988, 2015).

From this perspective, culture can be viewed as an extension of embodiment into the world of humanly created meaning. This insight may first have been expressed by philosopher Maurice Merleau-Ponty (1962: 146): "The body is our general medium for having a world ... Sometimes the meaning aimed at cannot be achieved by the body's natural means; it must then build itself an instrument, and it projects thereby around itself a cultural world." Yu (2014: 233) reminds us, in the same vein, that "the body does not terminate with the fleshy boundary of the skin, but rather extends out into its environment that is at once physical, social, and cultural, engaging in all sort of bodily and sociocultural interactions, so that the organism and environment are not independent, but rather interdependent aspects of the basic flow of bodily experience ... to fully understand the body, we will have to go beyond the body itself." The perspective of extended embodiment has been central to the recent shift from "neo-Whorfian" to "postWhorfian" research paradigms (Sinha and Bernárdez 2015).

\section{Cultural Linguistics}

Cultural linguistics is a relatively new term for a field with a long history, from von Humboldt to its designation by Palmer (1996: 36) as a synthesis "concerned with most of the same domains of language and culture that interest Boasians, ethnosemanticists and [ethnography of communication], [that] assumes a perspective ... that is essentially cognitive." Sharifian (2017: 2) also foregrounds the affiliative link between the concerns of $C L$ and cultural linguistics, which "engages with features of human languages that encode or instantiate culturally constructed conceptualizations encompassing the whole 
Chapter 37 in Xu Wen and John R. Taylor (Eds.) (2021) The Routledge Handbook of Cognitive Linguistics, pp. 387-407. Downloadable from https://psyarxiv.com/prm7u/Preprint DOI 10.31234/osf.io/prm7u

range of human experience." Sharifian (2017: 23) further proposes that "cultural schemas, cultural categories and cultural metaphors are the three main analytical tools of cultural linguistics", emphasizing theoretical concepts that interface directly with the concerns of both cultural psychology and psychological anthropology (Shore 1996). In the present author's view, what is important is not so much the axiomatic delimitation of the scope of cultural linguistics, as the recognition of the way in which advances in cognitive linguistics have lent a renewed impetus to the interdisciplinary study of language, culture and mind.

\section{Methods}

Researching language, cognition and culture depends on combining and comparing empirical findings obtained by using different methods, developed in different disciplinary contexts. The field of study is both interdisciplinary and multi-methodological. Mixing methodologies, and especially taking advantage of modern technologies for data recording and analysis, brings huge advantages, but also poses challenges because of the divergent assumptions underlying different methods. We start by briefly examining the main methods for obtaining data "in the field": that is, in non-laboratory situations of natural language use.

\section{Ethnography: field research and reflexivity}

Ethnography has been, since the time of Boas and Malinowski, the core, foundational method of the discipline of anthropology, and as such is indispensable for interdisciplinary approaches to language and culture. Sharifian (2017: 41) rightly suggests that linguistic ethnography is not so much a "set procedure" for "data collection" as an epistemology, better characterized as a "set of procedures for data collection and analysis". I would also wish to profile a key attribute of the meta-methodological or epistemological stance inherent in ethnography: reflexivity. Reflexivity refers to the self-reflection inherent in all qualitative social scientific methods whose object is the elucidation of meaning (Sinha 2017a), which, given the indispensable requirement for interpretation on the part of the researcher, is irreducible to procedures. The reflexivity of interpretation involves a continuous revisiting of the researcher's findings and conclusions (which are always provisional) in the light of new observations and analyses, and against the background of the researcher's interrogation of their own culturally grounded presuppositions.

Ethnography, it is often said, is an art as much as a science (Carrithers et. 1990), and as such it is not only an epistemology / methodology for the construction of knowledge, but a practice of deliberate and 
Chapter 37 in Xu Wen and John R. Taylor (Eds.) (2021) The Routledge Handbook of Cognitive Linguistics, pp. 387-407. Downloadable from https://psyarxiv.com/prm7u/ Preprint DOI 10.31234/osf.io/prm7u

deliberative (inter-)cultural encounter-an encounter that goes under the name of "fieldwork".

Grinevald and Sinha (2016: 28) conceptualize the skills involved in fieldwork as "knowledge as practice / practice as knowledge", which "can be thought of as encompassing both the 'know-how' that underpins field research, and the reflexive stance that is theoretically enjoined upon researchers in all disciplines that employ qualitative research methods. It includes, but is not reducible to, knowledge of how to use technical equipment and software tools." In the past, the main tool at the disposal of the ethnographer for recording their findings was the (paper) field notebook. The field notebook still plays a key role in critical reflection and noting insights, but the $21^{\text {st }}$ century researcher is equipped not only with laptops and tablets, but also with sophisticated audio-video equipment that is complemented by software for coding and annotating data.

\section{Field experiments and ecological validity}

Behavioural experiment is at the same time an indispensable part of the methodological toolkit for investigating language, cognition and culture, and one of the most problematic methods. Experimental design in psychology is predicated on the laboratory context, in which extraneous and irrelevant variables are controlled for; and in which the sampling of participants (and the statistical analysis of the data) usually assumes that they are drawn from the same larger population, sub-groups being differentiated only by clearly defined demographic variables. Cross-cultural psychology traditionally relies upon administering the same experimental procedures, using the same experimental materials, to populations with different national or cultural backgrounds. However, as had already been understood by Gestalt psychologists, the same physical stimulus may have different meanings for different subjects in different contexts.

The recognition that using standardized materials and procedures can introduce biases that may disadvantage "non-Western" (or ethnic minority) populations was fundamental to the "experimental anthropology" pioneered by Michael Cole and his colleagues (see above). As the distinguished cognitive psychologist George A. Miller put it in his Preface to Cole et al. (1971: ix), "most psychologists are poorly prepared by education or acculturation to understand the mental processes of people living in ... traditional cultures or to grasp the full implications of the fact that such people's experiences have not required them to develop and use many of the cognitive strategies that our Western experience has instilled in us." For this reason, Cole et al. (1971: 217) rejected the possibility that experimental studies can yield valid cultural comparisons in the absence of ethnographic research to identify settings and 
Chapter 37 in Xu Wen and John R. Taylor (Eds.) (2021) The Routledge Handbook of Cognitive Linguistics, pp. 387-407. Downloadable from https://psyarxiv.com/prm7u/Preprint DOI 10.31234/osf.io/prm7u

practices that can serve to both guide the construction of experimental tasks, and to enable the researcher to interpret the participants' responses. This is the reasoning behind the requirement that comparative cognitive studies must employ ecologically valid methods (Cole et al. 1978), which will involve at a minimum the adaptation of materials and procedures to local conditions. Similarly, Dasen et al. $(2018: 328,338)$ recommend that instead of comparing cultural groups' performances on identical tasks, cultural psychologists should employ an ethnographically grounded design involving "a series of cumulative studies, with comparable methods".

\section{Descriptive and documentary linguistics}

There is a long tradition of linguists "going to the field" in order to gather information to describe and analyse previously unstudied or understudied languages. The canonical goal of this work was the "Boasian trilogy": grammar, text collection, (bilingual) dictionary; in the service (if the field linguist was a Christian missionary) of the translation of the Bible into the language under investigation. Traditionally, descriptive linguists have used word lists and sentence lists to elicit utterances in the target language. Descriptive linguistics has, during the last two decades, been complemented by documentary linguistics, whose goals may include, alongside documentation of endangered languages, their preservation and revitalization (Austin and Sallabank 2011). The contemporary toolkit of the descriptive linguist includes, as well linguistic theory, audio-visual recording equipment and elicitation tools, which often take the form of photos, drawings or video-clips of objects, actions, situations and narrative sequences. Usually, the researcher will work together with a small number of bilingual native speaker language consultants. The main methodological risk with using language elicitation tasks is that language consultants will reject the task or the task materials as inappropriate, or interpret them differently from the way the researcher expects them to be interpreted. Similar strictures therefore apply to the use of language elicitation procedures as those mentioned in relation to experiments. The researcher should employ ethnographic methods (observation and interview) in order to establish whether the tasks and depictions are appropriate for the field situation, and acceptable to the language consultants as depictions of whatever is intended to be depicted.

\section{Other methods}

Investigating cultural conceptualizations does not always involve field research. It may involve analysis of text and speech corpora (Gries 2016), both contemporary and historical, in order to identify specific usages (e.g. culturally specific discourse metaphors). Furthermore, not all research in language and 
Chapter 37 in Xu Wen and John R. Taylor (Eds.) (2021) The Routledge Handbook of Cognitive Linguistics, pp. 387-407. Downloadable from https://psyarxiv.com/prm7u/Preprint DOI 10.31234/osf.io/prm7u

culture is designed to investigate cultural conceptualizations. Performatively and pragmatically oriented ethnographies of communication will often employ the methods of Conversation Analysis (Liddicoat 2011) and its multimodal variants.

\section{Technologies: making field data ready for analysis}

Ethnographic, field experimental and field linguistic methods are ways of obtaining data on a given language in more-or-less naturalistic situations. The availability of affordable audio-video recording equipment means that not only conversations and interviews, but also experimental and language elicitation sessions carried out in the field, are nowadays recorded. This brings with it the need for software tools that can prepare the data for analysis (and can often be used for the analysis itself). Video recording makes possible the simultaneous analysis of language and nonlinguistic actions, both non-communicative (e.g. the making of artefacts) and communicative (e.g. gesture, gaze, body posture and orientation). Multimodal analysis is increasingly important in the study of language use in its cultural and situational context. A crucial tool for all kinds of language and language-related data is software for annotating and transcribing multimodal interactions, such as ELAN, developed at the MaxPlanck Institute for Psycholinguistics. ${ }^{7}$ Annotation of utterances in understudied languages will usually take the form of interlinear morpheme-by-morpheme glosses (Comrie et al. 2008), in which (in addition to morpheme glosses) one or more linked lines (tiers) annotate utterances employing pre-established coding categories, depending on the specific research questions. Field experimental data can also be coded using annotation and transcription software. Coded data from spontaneously occurring interactions, interviews, elicitation and experimental sessions can be exported if desired to other software, such as spreadsheets, acoustic tools and/or statistical packages.

\section{Culturally informed linguistic analysis}

The next step is the analysis of the data to illuminate salient cultural motivations of grammatical and lexical patterns, or patterns of nonlinguistic responses in field experiments, and to identify "the cultural conceptualizations that underlie the use of that language for meaning making" (Sharifian 2017: 41). Sharifian (pp. $41 \mathrm{ff}$ ) summarizes some data analysis procedures that are commonly and usefully employed in cultural linguistic research. These are: conceptual-associative analysis; conceptual analysis of story recounts; (meta-) discourse analysis; corpus analysis; ethnographic-conceptual text/visual analysis; diachronic / synchronic conceptual analysis. With the exception of corpus analysis, these are all qualitative analytic procedures, for which the researcher may choose to employ either the analysis tools 
Chapter 37 in Xu Wen and John R. Taylor (Eds.) (2021) The Routledge Handbook of Cognitive Linguistics, pp. 387-407. Downloadable from https://psyarxiv.com/prm7u/ Preprint DOI 10.31234/osf.io/prm7u

in freeware such as ELAN, or commercial qualitative analysis software such as NVIVO ${ }^{8}$ or ATLAS.ti. ${ }^{9}$ Corpus analyses, and analyses of field experimental and elicited language data, will also apply quantitative statistical procedures to coded data, using software packages, sometimes in combination with qualitative protocol analyses. However, no analytic procedure, however well-conducted, will yield valid insights into the cultural motivations of language patterns and conceptualizations in the absence of ethnographically-grounded knowledge of their social, communicative and historical contexts. For this reason, the crucial importance of field research by native speakers, and of the systematic training of native speaker researchers in field linguistic methods, is increasingly recognized as vital for cultural and typological linguistic research, as well as for language description, documentation and revitalization (Cabral et al. 2016).

\section{What is good field research?}

In all cases, the qualitative and quantitative analytic procedures that are used in relation to the dataset will be motivated by the research question(s) that the analyst is attempting to answer. The results of the analysis will only ever be as good as the data that are being analysed. It cannot be over-emphasized that the most important methodological requirement for field investigations of language, culture and cognition is that the researcher must establish and maintain a relationship of trust with the members of the community with whom they are working; including in situations where the researcher is themselves a member of the community and a native speaker. Good field research means carefully explaining the goals of the research to the participants, ensuring that the methods are mutually understood and agreed to be valid, culturally appropriate ways of investigating the topic under investigation. In addition to the ethical norms that should apply to all research with human participants, good practice now requires that the results of the research will be made available to researched communities in a way that they can understand, in order to use them for their own purposes, including education for revitalisation.

\section{Key Research Topics}

\section{Colour}

The domain of colour has been central to the rise and fall of what came to be known as the 'Whorf hypothesis': the 'linguistic determinist' interpretation of linguistic relativity. Popular science has long employed the trope of "the many Eskimo names for snow." ${ }^{10}$ This gave rise to the hypothesis that codable categories (those that are lexicalized, preferably by single morphemes) are more cognitively and perceptually salient than categories that are not lexically coded in this way. The hypothesis received 
Chapter 37 in Xu Wen and John R. Taylor (Eds.) (2021) The Routledge Handbook of Cognitive Linguistics, pp. 387-407. Downloadable from https://psyarxiv.com/prm7u/ Preprint DOI 10.31234/osf.io/prm7u

some (subsequently contested) support from experiments on colour recognition and recall (Brown \& Lenneberg, 1954). An opposing universalist and evolutionary hypothesis was proposed by Berlin and Kay (1969), who proposed an invariant, 7-stage sequence of emergence across languages of 'basic colour terms' (BCTs) (which must consist of single morphemes referring only to colour, and not to any other material substance or attribute). According to their hypothesis, all languages have words for black (dark) and white (light); if they have three BCTs, the third will be red; if they have four BCTs, the fourth will be green, or yellow, or a term covering both green and yellow; and so forth up to a maximum of 11 BCTs, which happens to be the number in English. ${ }^{11}$ The BCTs were hypothesized to name categories centred on universal focal colours rooted in the neurophysiology of colour perception (Kay and McDaniel 1978). Support for Berlin and Kay, and evidence against the codability hypothesis, was provided by research by Rosch (1973) who showed that speakers of the Dani language of Papua New Guinea, which has only two BCTs (for light and dark), learned and remembered invented names for other focal colours (unlabelled in the language) better than invented names for non-focal colours. ${ }^{12}$

The BCT research paradigm depends upon the use of a particular elicitation procedure, using the Munsell colour chart, which consists of an array of colour samples organized according to gradations of hue, brightness and saturation (Nickerson 1940). This use of 'disembodied and disembedded' stimuli; the assumption that the semantic domain of colour is categorized on the basis of unmediated sense perception; the nativist account of focal colours; the neglect of social-historical and technological influences on colour terminology; and the theory's ethnolinguistic bias have all been criticized by a number of authors, of universalist (Wierzbicka 1990, 2006), relativist (Lucy 1997) and critical-historicist (Saunders 2006) persuasions. Wierzbicka (1990: 99) argues, for example, that "colour concepts are anchored in certain 'universals of experience' [that] can be identified as day and night, fire, the sun, vegetation, the sky, and the ground ... to be able to communicate about [colour sensations] we project them onto something in our shared environment." Lucy (1997: 341) argues in a similar vein that "communicatively relevant encodings of visual experience do not lie 'in there' in the biology but out there in socially anchored linguistic systems." Saunders (2006: 96) argues that these 'socially anchored linguistic systems' include the philosophical and scientific discourses that surround the notion of 'visual perception', arguing that 'if 'colour' is a coherent concept at all it is an artefactual kind, not a natural kind". 
Chapter 37 in Xu Wen and John R. Taylor (Eds.) (2021) The Routledge Handbook of Cognitive Linguistics, pp. 387-407. Downloadable from https://psyarxiv.com/prm7u/ Preprint DOI 10.31234/osf.io/prm7u

Viewed in this light, the differentiation of BCTs from 'non-basic' colour terms; their identification with an inventory based upon 11 English colour terms - that are not in strict correspondence with, for example, 11 identified Chinese BCTs (Xue 2020); and the BCT research paradigm as a whole, might be regarded as methodological artefacts flowing from a "radical universalist position [that] not only seeks universals, but sets up a procedure which guarantees both their discovery and their form" (Lucy 1997: 331-332). Lucy continues (p. 332) by stating his own conviction that "there are universal patterns to the semantic treatment of the phenomena we call color perception, but ... they bear a very indirect relationship to the findings of the $[\mathrm{BCT}]$ tradition." Despite this, it should be acknowledged that the BCT programme has resulted in a large cross-linguistic database of colour terms, and later research in the BCT tradition has modified and elaborated the theory in respect both of hypothesized neurocognitive processes and of cultural influences on categorization (Maclaury 1997; Kemmerer 1999).

What, though, of the question that originally provoked modern research into language and colour: universalism vs relativity? Roberson et al. (2006: 160) summarize the results of their extensive research program as follows: "cross-cultural studies of colour categorization [in adults] have found consistent differences in a range of perceptual and memory tasks, systematically linked to the colour categories in each culture." Roberson et al. also summarize the results of their child developmental studies (pp. 166168) "The advantage [in naming and memory tasks] for items [central to the BCTs] ... increased throughout the longitudinal study ... focality is not universal but ... language dependent [and] children ... progress gradually from an uncategorized organization of colour based on similarity to a structured organization of categories that varies across languages and cultures." These results both support a Vygotskian interpretation of neo-Whorfian effects, and (although there is not space here to expand this point) provide a point of contact with the revised BCT account proposed by MacLaury (1997).

\section{Space and Time}

The cognitive and linguistic domains of space and time occupy a special place both in Western philosophy of mind, dominated by universalist assumptions, and in cognitive linguistics, in which conceptualizations of spatial relations have been fundamental to cognitive semantics, cognitive grammar and cognitive typology (Lakoff, 1987; Langacker 1987; Talmy 2000). Space and time have been key to explorations in the last three decades of variation in cognition and language, and to the development of neo-Whorfian and post-Whorfian theories. 
Chapter 37 in Xu Wen and John R. Taylor (Eds.) (2021) The Routledge Handbook of Cognitive Linguistics, pp. 387-407. Downloadable from https://psyarxiv.com/prm7u/ Preprint DOI 10.31234/osf.io/prm7u

\section{Spatial frames of reference (FoR)}

Spatial FoR refers to the coordinate system in terms of which the spatial relationship between a figure and ground is conceptualized. For example, the same spatial scene, in which the speaker stands outside and at the stern of a boat, downstream of and facing the boat, may be conceptualized as 'the boat is in front of me' (relative FoR), 'I am behind the boat' (intrinsic FoR) and 'I am downriver from the boat' (absolute FoR). The large-scale cross-linguistic research program on spatial FoR carried out by Stephen Levinson (2003) and colleagues was fundamental to the re-evaluation of linguistic relativity from the 1990s onwards (see also Brown 2014). They first documented an astonishingly wide degree of variation between languages in their spatial FoR, including absolute FoR languages in which cardinal points (NSEW), topography or geography is used for all spatial linguistic conceptualizations; so that a speaker must refer to a companion as being e.g. 'to the south', 'upriver', 'towards the mountains', 'towards the ocean' (as opposed to 'to the left'). They further documented that differences in speakers' use of cospeech gestures parallel differences in linguistic FoR, a finding that prefigured the widespread use in $\mathrm{CL}$ research of multimodal communication methods. Finally, they showed that participant strategies in tasks involving memory for spatial arrays also parallel differences in linguistic FoR. Since the project sampled languages with the same spatial FoR but otherwise different cultural profiles, it was an important support for the hypothesis that differences in nonlinguistic cognition (as established by experiment and elicitation) are due to language variation independently of cultural variation. This is a key tenet of present-day neo-Whorfian theories and associated research designs, although Brown (2014: 302) calls for more research into the "interpenetration" of language, culture and thought in cultural contexts.

\section{Cultural embodiment in spatial language development}

A contrasting (and explicitly interdependence-oriented) approach was taken in cross-cultural and crosslinguistic research on children's development of spatial language and concepts by the present author and his colleagues (e.g. Jensen de López et al. 2005), who compared language comprehension strategies and nonlinguistic action imitation in Danish, Japanese and Zapotec acquiring children. The research led to the substantive conclusion that "language acquiring children are 'predisposed', through their experiences of interaction with the material world as this is culturally presented, and through the mediation of cultural practices, to employ [cognitive and linguistic] strategies that are consistent with the specific semantics of the languages they are acquiring. Acquisition of, and experience of using, language subsequently entrenches this socio-culturally based cognitive difference (rather than, as in the 
Chapter 37 in Xu Wen and John R. Taylor (Eds.) (2021) The Routledge Handbook of Cognitive Linguistics, pp. 387-407. Downloadable from https://psyarxiv.com/prm7u/Preprint DOI 10.31234/osf.io/prm7u

conventional reading of the Whorfian hypothesis, causing or determining it)" (Sinha and Jensen de López 2000: 36). As well as offering a theoretical account based on the concept of extended cultural embodiment, this research also reinforces a methodological tenet that is central to cultural psychology (Valsiner 1995) - namely that language and culture cannot be conceptualized as "independent variables."

\section{Temporal concepts in language and culture}

Languages conceptualize time in very different ways, and the study of temporality and 'time reckoning' in different cultures has been a major topic in anthropology for many years (Munn 1992). It has often been noted that until quite recently different cultures, faith groups and nations used different calendric systems, each with its own cultural or religious significance. To this day, although the world has adopted a single standard calendar for official life (ISO 8601:2004: originally the Western Christian luni-solar Gregorian calendar), different calendars (for example the traditional Chinese lunar calendar) co-exist with it in many cultures.

Calendars are historical inventions, as are clocks (Postill 2002), whose function is to measure 'time' in terms of intervals of duration. For this reason, calendar and clock time can be referred to as metric time (Sinha and Gärdenfors 2014). It has also been remarked (e.g. Evans-Pritchard 1940) that in many cultures calendar and clock time is absent, vague or subordinated to 'ecological time', but little attention has been paid to the cultural linguistic analysis of non-metric time concepts. Recent research has investigated event-based time in Amazonian cultures and languages that have small number systems (of the kind already noted by Boas - see above) and correspondingly have no metric time systems such as clock or calendar time. This research has shown that event-based time intervals are organized as complex systems of lexicalized time intervals, grounded in and indexed to the seasonal and diurnal rhythms of the natural environment, and the regulative norms governing social life and human development (Sinha et al. 2011; Silva Sinha et al. 2012; Silva Sinha 2019). Event-based time intervals (unlike metric time intervals) are found in all cultures and languages, and all metric time systems can be assumed to have culturally-historically evolved out of them. For example, the "canonical hours" for prayer in Christian monasteries (as codified in medieval "books of hours": Brown 2017) evolved into a more regular, metric 'clock time'. 
Chapter 37 in Xu Wen and John R. Taylor (Eds.) (2021) The Routledge Handbook of Cognitive Linguistics, pp. 387-407. Downloadable from https://psyarxiv.com/prm7u/Preprint DOI 10.31234/osf.io/prm7u

\section{Space-time metaphorical mapping}

It is difficult in English to speak of temporal relations between events without employing words and constructions whose primary meanings are spatial. For example, we may party through the night then take a day off on Sunday. We may be coming up to graduation, and the deadline for an essay may be rapidly approaching. The conceptualization of time in terms of spatial relations and motion in space is to be found in a very wide range of languages and cultures (Haspelmath, 1997; Núñez and Cooperrider 2013) and is probably present in the vast majority of languages. It has been proposed on this basis that the conceptual metaphor TIME IS SPACE is universal (Lakoff and Johnson 1999; Fauconnier and Turner 2008).

Constructions such as 'my birthday is coming' and ' $I$ ' $m$ coming up to my $30^{\text {th' }}$ involve either the imaginary movement of the viewpoint of an experiencer along a mental timeline (MT), or the imaginary movement of an event along a MT. In the majority of languages the viewpoint is that of an experiencer who is facing towards the future, but in the Andean language Aymara there is evidence both from language and from co-speech gesture that the experiencer is facing the past (Núñez and Sweetser 2006). Do we, however, find a mental timeline represented in all languages? If the MT is an innate property of the human mind, as hypothesized by Hoerl and McCormack (2019), we would expect that to be the case. However, it is not: several unrelated languages have been documented in which there appears to be no mental timeline manifested in speech, gesture or sign (e.g. LeGuen and Pool Balam 2012; Le Guen 2017; Silva Sinha 2019).

In the Amazonian languages studied by Silva Sinha (2019), not only was there no evidence of a linguistic MT, but the metaphors for time were based not on spatial direction and orientation, but on embodied perception and cognition: for example THE PAST IS IN MY HEART; THE FUTURE IS IN MY HEAD. These findings support a post-Whorfian account in which the mental timeline has a cultural historical origin, based in the invention of symbolic cognitive artefacts such as calendric systems, rather than being innate.

\section{Self and Identities}

The previous two topics have been central for many years to research and theory development in language, cognition and culture. The third topic I briefly address here is of more recent interest to cultural linguists in the cognitive tradition, but similarly to the other two topics it is rooted in fundamental theoretical propositions of cognitive linguistics, in particular embodiment theory; and in continuing work on the linguistic expression of 'the body in the mind' (Johnson 1987). An important 
Chapter 37 in Xu Wen and John R. Taylor (Eds.) (2021) The Routledge Handbook of Cognitive Linguistics, pp. 387-407. Downloadable from https://psyarxiv.com/prm7u/ Preprint DOI 10.31234/osf.io/prm7u

research strand in the investigation of cultural conceptualizations has been the comparative study of the metaphorical mapping of body parts and internal organs in different cultures to mental processes such as thinking and emotion-for example, vision or hearing as metaphorical loci for understanding; the heart vs the abdomen as the metaphorical seat of emotion (e.g. Evans and Wilkins 2000; Sharifian et al. 2008; Yu 2009). However, it is only more recently that researchers have turned their attention to the cultural conceptualization of the individual locus of the human mind: the self.

In contrast, the study of cultural concepts of the self, and their historical origin, is a relatively wellestablished area of anthropological psychology (Marsella et al. 1985) and philosophical anthropology (Taylor 1989). Cross-cultural psychological studies have shown that Western (principally American) experimental participants tend to conceptualize the self as independent, bounded and autonomous, while non-Western (principally East Asian) participants tend to conceptualize the self as interdependent, relational and rooted in networks of social obligation (e.g. Markus and Kitayama 1991). Such studies have resulted in interesting generalizations, but they risk over-generalization, over-simplification and the tendency to bracket highly variant cultural formations together. Anthropologists have tended to focus less on conceptualizations of self, and more on socially situated and discursively constructed concepts such as identity and belonging, in specific cultural contexts, and especially in relation to gendered, ethnic and migratory identities (Casey and Edgerton 2005).

Cognitive-cultural linguists are now beginning to turn their attention to this field. A notable and important recent study by Lu (2019) focuses on migrant selves and identities in the Chinese diaspora population of Australia, employing methods and concepts both from embodiment theory, and from the performative approach of ethnography of communication. Another recent collection focuses on self and identity from both cognitive-cultural linguistic and interdisciplinary perspectives (Silva Sinha et al. 2020). It can be anticipated that this topic (or cluster of topics) will receive increasing attention in coming years, with an orientation to the complex and culturally situated inter-relations between self, identity and (inter-) subjectivity in communication and cognition.

\section{Future Directions}

Over the past decades, an increasingly rich variety of languages has been studied by cognitive linguists. Cognitive linguistics today is a proudly multilingual enterprise. It is no surprise, then, that cognitive linguists have shown an increasing interest in the diverse cultural models and schemas that motivate the semantics and grammar of different languages. This development has given rise, as we have seen, to the 
Chapter 37 in Xu Wen and John R. Taylor (Eds.) (2021) The Routledge Handbook of Cognitive Linguistics, pp. 387-407. Downloadable from https://psyarxiv.com/prm7u/ Preprint DOI 10.31234/osf.io/prm7u

growing engagement of researchers in the field of CL-based cultural linguistics. I have no crystal ball, but I will venture the following predictions:

- Research topics will expand beyond those that are most directly based in embodiment theory, conceptual metaphor and related core CL areas, to encompass topics and methods currently mainly studied in anthropological linguistics. There will be an increasing engagement by linguists with other social sciences studying culture, mind and language, especially anthropology and psychology.

- The fundamental proposition of $\mathrm{CL}$, that language is grounded in the human brain and body in its ecological context, will be expanded to explicitly recognize that this ecological context is socio-culturally constructed and socio-culturally variable, and that all cognition is socio-culturally situated cognition.

- There will be increasing acknowledgement that neither 'cultures' nor 'languages' are essentialist entities that are uniformly distributed amongst distinct communities. Cultures interact, they are composed of individuals who do not all share the same cultural capital, and who may have multiple cultural identities. Languages influence each other through competition as well as contact, and multilingual speakers possibly outnumber monolingual speakers in the world's population. Our own cultural models as language researchers will increasingly need to accommodate these realities.

\footnotetext{
${ }^{1}$ Cited in Spencer-Oatey (2012:1).

${ }^{2}$ While Ferdinand de Saussure is usually credited with founding modern linguistics, Boas, with his focus on "lesser known" languages, might be regarded as having an equally valid claim. Usually, however, he is seen as "the father of American anthropology". The overview in this section of language and culture in anthropology focuses on the Boasian tradition, which continues to be influential, especially in the Americas. Sadly, despite the pioneering work of Malinowski, the language-culture relationship has received little attention in later British social anthropology (Henson 1974), other than through a recent orientation in social constructionist theories to discourses and the discursive construction of subject positionings. Both this approach, and the Continental European tradition of structuralism and post-structuralism, lie outside the scope of this chapter.

${ }^{3}$ Boas was apparently the first scholar to use in English the term 'cultures' in the plural; although the plural had previously been used by German cultural psychologists such as Steinthal and Wundt who influenced Boas (Leavitt, p.c.).

${ }^{4}$ This author (Sinha 2017b: 168-170) distinguishes a Boasian "positive relativism" from a "negative relativism" that can be identified with solipsism and scepticism.

${ }^{5}$ Although Piagetian and Vygotskian theories have often been cast as conflicting with each other, more recent evaluations have stressed that they can be seen as complementary (Bronckart, 2012).

${ }^{6}$ It is worth noting that non-human animal cognition is nowadays known to be more similar to that of humans than was thought by the originators of the theory of semiotic mediation. This issue is beyond the scope of this chapter, but in this author's view it remains plausible to attribute many of the human/non-human cognitive differences that do exist to the use by all human communities of language and other communicative and cognitive signs.

${ }^{7}$ See Sloetjes and Wittenburg (2008). ELAN software available for download from https://archive.mpi.nl/tla/elan

${ }^{8}$ https://www.qsrinternational.com/nvivo-qualitative-data-analysis-software/home
} 
Chapter 37 in Xu Wen and John R. Taylor (Eds.) (2021) The Routledge Handbook of Cognitive Linguistics, pp. 387-407. Downloadable from https://psyarxiv.com/prm7u/ Preprint DOI 10.31234/osf.io/prm7u

${ }^{9}$ https://atlasti.com/product/

${ }^{10}$ Although it has sometimes been claimed that 'the many Eskimo names for snow' is an invented fiction, the example, with detailed linguistic specification, can in fact be found in Boas (1911: 25-26).

${ }^{11}$ At least two languages, Russian and Polish, have one more BCT than English (Davies and Corbett 1994; Wierzbicka 1990).

${ }^{12}$ This work set the scene for the development by Rosch of prototype theory (see Chapter XX).

\section{Acknowledgements}

I am grateful for the insightful comments of Peter Austin and John Leavitt that, I hope, have helped me improve this chapter. Remaining shortcomings are entirely mine. I also wish to express my sadness at the untimely death in May 2020 of Farzad Sharifian, who contributed so much to the field of cultural linguistics, and still had so much give.

\section{Further Reading}

\section{Textbooks and overview works}

Foley, W.A. (1997) Anthropological Linguistics: An Introduction. Oxford: Blackwell Publishing.

Sharifian, F. (2017) Cultural Linguistics. Amsterdam, John Benjamins.

Shore, B. (1996) Culture in Mind: Cognition, culture and the problem of meaning. Oxford: Oxford University Press.

Sinha C. (2017). Ten Lectures on Language, Culture and Mind. Cultural, developmental and evolutionary perspectives in cognitive linguistics. Leiden: Brill.

\section{Edited Collections}

Sharifian, F. (Ed.) (2015) The Routledge Handbook of Language and Culture. New York: Routledge.

Silva, A. S. da, Torres, A. and Gonçalves, M. (2004). Linguagem, Cultura e Cognição: Estudos de Lingüística Cognitiva (2 vols.) Coimbra: Livraria Almedina.

Journal

International Journal of Language and Culture. Published by John Benjamins Publishing Company. https://www.benjamins.com/catalog/ijolc 
Chapter 37 in Xu Wen and John R. Taylor (Eds.) (2021) The Routledge Handbook of Cognitive Linguistics, pp. 387-407. Downloadable from https://psyarxiv.com/prm7u/Preprint DOI 10.31234/osf.io/prm7u

\section{Related Topics}

(to be added)

\section{References}

Austin, P. K. (2016). Language documentation 20 years on. In L. Filipovic, \& M. Pütz (Eds.) Endangered Languages and Languages in Danger (pp. 147-170). Amsterdam: John Benjamins.

Austin, P. K., \& Sallabank, J. (Eds.). (2011). The Cambridge Handbook of Endangered Languages. Cambridge: Cambridge University Press.

Berlin, B., \& Kay, P. (1969). Basic Color Terms: Their universality and evolution. Berkeley: University of California Press.

Berry, J. W. (1969). On cross-cultural comparability. International Journal of Psychology 4: 119-128.

Boas, F. (1896). The limitations of the comparative method of anthropology. Science, 4(103), 901-908.

Boas, F. (1911). Introduction. Handbook of American Indian Languages, Vol. 1. Smithsonian Institution Bureau of American Ethnology, Bulletin 40. Washington: Government Print Office, 1-83.

Bronckart, J.-P. (2012). Contributions of Piagetian Constructivism to Social Interactionism. In E. Martí \& C. Rodríguez (Eds.) After Piaget. New Brunswick, NJ: Transaction Publishers: 43-58.

Brown, P. (2015). Language, culture and spatial cognition. In Sharifian, F. (Ed.) The Routledge Handbook of Language and Culture. New York: Routledge, 294-308.

Brown, R. F. (2017). Mary and the Art of Prayer: The Hours of the Virgin in Medieval Christian Life and Thought. NY: Columbia University Press.

Brown, R., \& Lenneberg, E. (1954). A study in language and cognition. Journal of Abnormal and Social Psychology 49: 454-462.

Cabrial, A.S.C.C., Sampaio, W.B.A. \& Silva Sinha, V. da (2016) Indigenous language policies in Brazil: training indigenous people as teachers and researchers. In L. Filipovic, \& M. Pütz, Endangered Languages and Languages in Danger (pp. 45-59). Amsterdam: John Benjamins. 
Chapter 37 in Xu Wen and John R. Taylor (Eds.) (2021) The Routledge Handbook of Cognitive Linguistics, pp. 387-407. Downloadable from https://psyarxiv.com/prm7u/ Preprint DOI 10.31234/osf.io/prm7u

Carrithers, M., Barry, A., Brady, I., Geertz, C., Keesing, R. M., Roth, P. A., ... \& Whittaker, E. (1990). Is anthropology art or science? [and Comments and Reply]. Current Anthropology 31: 263-282.

Casey C. and Edgerton, R.B. (Eds.) (2005) A Companion to Psychological Anthropology: Modernity and psychocultural change. Blackwell Companions to Anthropology. Oxford: Blackwell Publishing Ltd.

Clifford, J., and Marcus, G. (1986). Writing Culture: The poetics and politics of ethnography. Berkeley: University of California Press.

Cole, M., Gay, J., Glick, J. A., \& Sharp, D. W. (1971). The Cultural Context of Learning and Thinking: An exploration in experimental anthroplogy. London: Tavistock Publications.

Condillac, E.B., Abbé de (1987 [1746]). Philosophical Writings Vol. 2, transl. F. Philip. N.J.: Lawrence Earlbaum.

Cole, M., Hood, L., \& McDermott, R. (1978). Ecological niche picking: Ecological invalidity as an axiom of experimental cognitive psychology. Rockefeller University, Laboratory of Comparative Human Cognition.

Comrie, B., Haspelmath, M., \& Bickel, B. (2008). The Leipzig Glossing Rules: Conventions for interlinear morpheme-by-morpheme glosses. Department of Linguistics of the Max Planck Institute for Evolutionary Anthropology and the Department of Linguistics of the University of Leipzig. https://www.eva.mpg.de/lingua/resources/glossing-rules.php

Darnell, R. (2006). Benjamin Lee Whorf and the Boasian foundations of contemporary ethnolinguistics. In Jourdan, C. \& Tuite, K. Language, Culture and Society: Key topics in linguistic anthropology. Cambridge: Cambridge University Press pp. 82-95.

Dasen, P. R., Mishra, R. C., \& Wassmann, J. (2018). Quasi-experimental research in culture sensitive psychology. Culture \& Psychology, 24(3), 327-342. https://doi.org/10.1177/1354067X18779043

Davies, I., and Corbett, G. (1994). The basic color terms of Russian. Linguistics, 32: 65-90.

Duranti, A. (2003). Language as culture in US anthropology: three paradigms. Current Anthropology 44: 323-347.

Evans, N., \& Wilkins, D. (2000). In the mind's ear: The semantic extensions of perception verbs in Australian languages. Language 76: 546-592. 
Chapter 37 in Xu Wen and John R. Taylor (Eds.) (2021) The Routledge Handbook of Cognitive Linguistics, pp. 387-407. Downloadable from https://psyarxiv.com/prm7u/ Preprint DOI 10.31234/osf.io/prm7u

Fauconnier, G. and Turner, M. (2008). Rethinking metaphor. In Gibbs, R. (Ed.) The Cambridge Handbook of Metaphor and Thought. Cambridge: Cambridge University Press, 53-66.

Geertz, C. (1973). The Interpretation of Cultures. New York: Basic Books.

Goffman, E. (1967). Interaction Ritual: Essays on face-to-face behaviors. Garden City: Doubleday.

Grinevald, C. and Sinha, C. (2016). North-South relations in linguistic science: Collaboration or colonialism? In L. Filipovic, \& M. Pütz, Endangered Languages and Languages in Danger (pp. 2544). Amsterdam: John Benjamins.

Gries, S. T. (2016). Quantitative Corpus Linguistics with R: A practical introduction. London: Taylor \& Francis.

Gumperz, J., \& Hymes, D. (1972). Directions in Sociolinguistics: The ethnography of communication. New York: Holt, Rinehart and Winston.

Haspelmath, M. (1997). From Space to Time: temporal adverbials in the world's languages. Munich: Lincom.

Henson, H. (1974). British Social Anthropologists and Language: A history of separate development. Oxford: Clarendon Press.

Hoerl C. and McCormack T. (2019) Thinking in and about time: A dual systems perspective on temporal cognition. Behavioral and Brain Sciences 42, e244: 1-69.

Householder, F. W. (1975). Kenneth L. Pike, Selected writings ( to commemorate the 60th birthday of Kenneth Lee Pike ). Edited by Ruth M. Brend. The Hague: Mouton, 1972.

Humboldt, W. von (1999). On language: On the diversity of human language construction and its influence on the mental development of the human species. Cambridge: Cambridge University Press. Original publication (1836) Über die Verschiedenheit des menschlichen Sprachbaus und ihren Einfluss auf die geistige Entwicklung des Menschengeschlechts.

Hutto, D. D., Gallagher, S., Ilundáin-Agurruza, J., \& Hipólito, I. (2020). Culture in Mind - An Enactivist Account: Not cognitive penetration but cultural permeation. Unpub. Ms.

Jensen de López, K., Hayashi, M. and Sinha, C. (2005) Early shaping of spatial meanings in three 
Chapter 37 in Xu Wen and John R. Taylor (Eds.) (2021) The Routledge Handbook of Cognitive Linguistics, pp. 387-407. Downloadable from https://psyarxiv.com/prm7u/ Preprint DOI 10.31234/osf.io/prm7u

languages and cultures: linguistic or cultural relativity? In Makkai, A., Sullivan, W.J. and Lommel, A.R. (eds.) Selected Papers from the LACUS Forum XXXI 2003: Interconnections. Houston, Texas: Linguistic Association of Canada and the Unites States, pp. 379-388.

Johnson, M. (1987). The Body in the Mind: The bodily basis of meaning, imagination, and reason. Chicago: University of Chicago Press.

Jourdan, C., \& Tuite, K. (. (2006). Language, Culture and Society: Key topics in linguistic anthropology. Cambridge: Cambridge University Press.

Kay, P., \& Fillmore, C. J. (1999). Grammatical constructions and linguistic generalizations: the What's X doing $Y$ ? construction. Language, 75: 1-33.

Kay, P., \& McDaniel, C. K. (1978). The linguistic significance of the meanings of basic color terms. Language: 610-646.

Kemmerer, D. (1999). Neuroscientific evidence against Wierzbicka's analysis of the meanings of basic colour terms. In Hiraga, M.K., Wilcox, S. and Sinha, C. (Eds.) Cultural, Psychological and Typological Issues in Cognitive Linguistics. Amsterdam: John Benjamins, 249-268.

Köpping, K. P. (1983). Adolf Bastian and the psychic unity of mankind: The foundations of anthropology in nineteenth century Germany. LIT Verlag Münster.

Kroeber, A. L., \& Kluckhohn, C. (1952). Culture: a critical review of concepts and definitions. Papers. Peabody Museum of Archaeology \& Ethnology, Harvard University, 47(1), viii, 223.

Lakoff, G. (1987). Women, Fire and Dangerous Things: What categories reveal about the mind. Chicago: University of Chicago Press.

Lakoff, G. and Johnson, M. (1999). Philosophy in the Flesh: The embodied mind and its challenge to Western thought. New York: Basic Books.

Langacker, R. W. (1987). Foundations of Cognitive Grammar Vol. I. Stanford: Stanford University Press.

Lave, J., \& Wenger, E. (1991). Situated learning: Legitimate peripheral participation. Cambridge: Cambridge University Press. 
Chapter 37 in Xu Wen and John R. Taylor (Eds.) (2021) The Routledge Handbook of Cognitive Linguistics, pp. 387-407. Downloadable from https://psyarxiv.com/prm7u/Preprint DOI 10.31234/osf.io/prm7u

Le Guen, O. (2017) Una concepción del tiempo no-lineal en dos lenguas: el maya yucateco colonial y actual y la lengua de señas maya yucateca. Journal de la Société des Américanistes [online], URL: http:// journals.openedition.org/jsa/15327 ; DOI : 10.4000/jsa.15327

Le Guen, O., \& Pool Balam, L. I. (2012). No metaphorical timeline in gesture and cognition among Yucatec Mayas. Frontiers in Psychology (Cultural Psychology) 3: 271.

Leavitt, J. (2010). Linguistic relativities: Language diversity and modern thought. Cambridge, Cambridge University Press.

Lee, P. (1996). The Whorf Theory Complex: A critical reconstruction. Amsterdam: John Benjamins.

Levinson, S.C. (1996). Language and space. Annual Review of Anthropology, 25: 353-382.

Levinson, S.C. (2003). Space in language and cognition: Explorations in cognitive diversity. Cambridge: Cambridge University Press.

Levinson, S. C. and Gumperz, J. J. (Eds.). (1996) Rethinking Linguistic Relativity. Cambridge: Cambridge University Press.

Lévy-Bruhl, L. (1910). Les Fonctions Mentales dans les Societés Inférieures. Paris: Alcan.

Lévy-Bruhl, L. (1949). Les Carnets de Lévy-Bruhl. Paris: Presses Universitaire.

Liddicoat, A. J. (2011). An Introduction to Conversation Analysis. London: Bloomsbury Publishing.

Lucy, J. (1992a). Language Diversity and Thought: A reformulation of the linguistic relativity hypothesis. Cambridge: Cambridge University Press.

Lucy, John (1992b). Grammatical Categories and Cognition: A case study of the linguistic relativity hypothesis. Cambridge: Cambridge University Press.

Lucy, J. A. (1997). The linguistics of 'color'. In Hardin, C. L. and Maffi, L. (Eds.). Colour Categories in Thought and Language. Cambridge: Cambridge University Press, 320-346.

Luria, A. (1976). Cognitive Development: Its cultural and social foundations (Ed. Michael Cole). Cambridge, MA: Harvard University Press.

MacLaury, R. E. (1997). Color and Cognition in Mesoamerica: Constructing categories as vantages. Austin: University of Texas Press. 
Chapter 37 in Xu Wen and John R. Taylor (Eds.) (2021) The Routledge Handbook of Cognitive Linguistics, pp. 387-407. Downloadable from https://psyarxiv.com/prm7u/Preprint DOI 10.31234/osf.io/prm7u

Markus, H. R., \& Kitayama, S. (1991). Culture and the self: Implications for cognition, emotion, and motivation. Psychological Review 98: 224-253.

Marsella, A. J., De Vos, G. A., \& Hsu, F. L. (Eds.) (1985). Culture and Self: Asian and Western perspectives. New York: Tavistock Publications.

Merleau-Ponty, M. (1962). The Phenomenology of Perception. London: Routledge \& Kegan Paul.

Mertz, E. and Parmentier, R.J. (1985) Semiotic Mediation: Sociocultural and psychological perspectives. New York: Academic Press.

Morgan, L.H., (1877). Ancient Society; Or, Researches in the Lines of Human Progress from Savagery, Through Barbarism to Civilization. New York: H. Holt.

Munn, N.D. (1992). The cultural anthropology of time: a critical essay. Annual Review of Anthropology 21: 93-123.

Nickerson, D. (1940). History of the Munsell color system and its scientific application. JOSA 30: 575-586.

Núñez, R., \& Cooperrider, K. (2013). The tangle of space and time in human cognition. Trends in Cognitive Sciences 17: 220-229.

Núñez, R.E. and Sweetser, E. (2006). With the future behind them: convergent evidence from Aymara language and gesture in the crosslinguistic comparison of spatial construals of time. Cognitive Science 30: 401-450.

Palmer, G. (1996) Toward a Theory of Cultural Linguistics. Austin: University of Texas Press.

Pertierra, R. (2010). Lévy-Bruhl and Modes of Thought: A Re-Appraisal. Mankind, 14(2), 112-126.

Retrieved 4 26, 2020, from http://onlinelibrary.wiley.com/doi/10.1111/j.1835-

9310.1983.tb01257.x/abstract

Peterman, B. S. (2000). Levy-Bruhl in Piaget: Hermeneutic Analysis of Text and Context. Developmental Review, 20(3), 405-437. Retrieved 4 26, 2020, from https://sciencedirect.com/science/article/pii/s0273229799905038

Pike, K. (1972) Selected writings (to commemorate the 60th birthday of Kenneth Lee Pike). Edited by Ruth M. Brend. The Hague: Mouton. 
Chapter 37 in Xu Wen and John R. Taylor (Eds.) (2021) The Routledge Handbook of Cognitive Linguistics, pp. 387-407. Downloadable from https://psyarxiv.com/prm7u/ Preprint DOI 10.31234/osf.io/prm7u

Postill, J. (2002). Clock and calendar time: a missing anthropological problem. Time and Society 11(2/3): 251-70.

Roberson, D., Davidoff, J., Davies, I.R.L. and Shapiro, L. (2006). Colour categories and category acquisition in Himba and English. In Pitchford, N.J. and Biggam, C.P. (Eds.) Progress in Colour Studies Vol. Il Psychological Aspects. Amsterdam/Philadelphia: John Benjamins Publishing Company, 159-172.

Rosch, E. H. (1973). Natural categories. Cognitive Psychology, 4: 328-350.

Sacks, H., Schegloff, E., \& Jefferson, G. (1974). A simplest systematics for the organization of turn-taking for conversation. Language, 50, 696-735.

Sapir, E. (1949). Selected Writings in Language, Culture and Personality (David G. Mandelbaum, Ed.). Berkeley: University of California Press.

Saunders, B. (2006). The normativity of colour. In Biggam, C.P. and Kay, C.J. (Eds.) Progress in Colour Studies Vol. I Language and Culture. Amsterdam/Philadelphia: John Benjamins Publishing Company, 89-100.

Senft, G. (2007). Bronislaw Malinowski and linguistic pragmatics. Lodz Papers in Pragmatics, 3(1), 79-96.

Sharifian, F. (2017) Cultural Linguistics. Amsterdam, John Benjamins.

Sharifian, F., Dirven, R., Yu, N., \& Niemeier, S. (Eds.) (2008). Culture, Body, and Language: Conceptualizations of internal body organs across cultures and languages. Berlin: Walter de Gruyter.

Shore, B. (1996). Culture in Mind: Cognition, culture and the problem of meaning. New York: Oxford University Press.

Silva Sinha, V. da (2019). Event-based time in three indigenous Amazonian and Xinguan cultures and languages. Frontiers in Psychology (Cultural Psychology), 10: 454.

Silva Sinha, V. da, Sinha, C., Sampaio, W. and Zinken, J. (2012). Event-based time intervals in an Amazonian Culture. In Filipović, L. and Jaszczolt, K. (eds.) Space and Time in Languages and Cultures II: Language, Culture, and Cognition. Amsterdam: John Benjamins: 15-35. 
Chapter 37 in Xu Wen and John R. Taylor (Eds.) (2021) The Routledge Handbook of Cognitive Linguistics, pp. 387-407. Downloadable from https://psyarxiv.com/prm7u/Preprint DOI 10.31234/osf.io/prm7u

Silva Sinha, V. da, Moreno-Núñez, A., \& Tian, Z. (2020). Language, culture and identity: Signs of life. Amsterdam: John Benjamins.

Sinha, C. (1988). Language and Representation: A Socio-Naturalistic Approach to Human Development. Hemel Hempstead: Harvester-Wheatsheaf.

Sinha, C. (2007). Cognitive linguistics, psychology and cognitive science. In D. Geeraerts and H. Cuyckens (eds.) Handbook of Cognitive Linguistics. Oxford, Oxford University Press, pp. 1266-1294.

Sinha, C. (2015) Language and other artefacts: socio-cultural dynamics of niche construction. Frontiers in Psychology (Cognitive Science) 6: 1601. doi: 10.3389/fpsyg.2015.01601

Sinha, C. (2017a). Getting the measure of meaning. In Barbara Dancygier (Ed.) The Cambridge Handbook of Cognitive Linguistics. Cambridge: Cambridge University Press, pp. 493-497.

Sinha C. (2017b). Ten Lectures on Language, Culture and Mind. Cultural, developmental and evolutionary perspectives in cognitive linguistics. Leiden, Brill.

Sinha, C. and Bernárdez, E. (2015) Metaphors, maps and fusions: Space, time and space-time. In Sharifian, F. (Ed.) The Routledge Handbook of Language and Culture. New York: Routledge, pp. 309-324.

Sinha, C. and Gärdenfors, P. (2014). Time, space, and events in language and cognition: a comparative view. Annals of the New York Academy of Sciences, 1326: 72-81.

Sinha, C. and Jensen de López, K. (2000). Language, culture and the embodiment of spatial cognition. Cognitive Linguistics 11, 17-41.

Sinha, C., Silva Sinha, V. da, Zinken, J. and Sampaio, W. (2011). When time is not space: The social and linguistic construction of time intervals and temporal event relations in an Amazonian culture. Language and Cognition 3: 137-169.

Sloetjes, H., \& Wittenburg, P. (2008). Annotation by category - ELAN and ISO DCR. In Proceedings of the 6th International Conference on Language Resources and Evaluation (LREC 2008).

Spencer-Oatey, H. (2012). What is culture? A compilation of quotations. GlobalPAD Core Concepts. Available at GlobalPAD Open House http://www.warwick.ac.uk/globalpadintercultural 
Chapter 37 in Xu Wen and John R. Taylor (Eds.) (2021) The Routledge Handbook of Cognitive Linguistics, pp. 387-407. Downloadable from https://psyarxiv.com/prm7u/ Preprint DOI 10.31234/osf.io/prm7u

Talmy, L. (2000). Towards a Cognitive Semantics (2 vols) Cambridge, MA: MIT Press.

Taylor, C. (1989). Sources of the Self: The making of the modern identity. Cambridge: Cambridge University Press.

Trabant, J. (2000). How relativistic are Humboldt's "Weltansichten”? In Pütz, M. and Verspoor, M. (Eds.) Explorations in Linguistic Relativity. Amsterdam: John Benjamins, 25-44.

Tylor, E.B., (1865). Researches into the Early History of Mankind and the Development of Civilization. Edinburgh: J. Murray.

Valsiner, J. (1995). Editorial. Culture \& Psychology, 1, 5-10.

Vygotsky, L. S. (1978). Mind in society. The development of higher psychological processes. (M. Cole, V. John-Steiner, S. Scribner, \& E. Souberman, Eds.) Cambridge, MA: Harvard University Press.

Whorf, B. L. (2012). Language, thought, and reality: Selected writings of Benjamin Lee Whorf. MIT press.

Wierzbicka, A. (1990). The meaning of colour terms: semantics, culture, and cognition. Cognitive Linguistics 1: 99-150.

Wierzbicka, A. (1992). Talking about emotions: Semantics, culture, and cognition. Cognition \& Emotion, 6: 285-319.

Wierzbicka, A. (2006). The Semantics of Colour. In Biggam, C.P. and Kay, C.J. (Eds.) Progress in Color Studies Vol. I Language and Culture. Amsterdam/Philadelphia: John Benjamins Publishing Company, 1-24.

Yu, N. (2009) The Chinese Heart in a Cognitive Perspective: culture, body and language. Berlin: Walter de Gruyter.

Yu, N. (2014). Embodiment, culture and language. In Sharifian, F. (Ed.) The Routledge Handbook of Language and Culture. New York: Routledge. 